УДК $341.225 .5(98)$

DOI dx.doi.org/10.24866/1813-3274/2019-3/70-76

Вереина Л. В. ${ }^{1}$, Московский государственный институт международных отношений (Университет) МИД России, г. Москва, Россия

E-mail: vereinalarisa@mail.ru

Котлова А. В. ${ }^{2}$, Одинцовский филиал Московского государственного института международных отношений (Университета) МИД России, г. Москва, Россия

E-mail: a.kotlova@odin.mgimo.ru

\title{
ПРАВОВОЙ СТАТУС СЕВЕРНОГО МОРСКОГО ПУТИ: ФРАНЦУЗСКАЯ ДОКТРИНА
}

Аннотация. Правительство Российской Федерации утвердило план развития инфраструктуры Северного морского пути (далее - СМП) до 2035 г. Грузооборот Северного морского пути к 2035 г. должен увеличиться в восемь раз, достигнув показателя в 160 млн т. Российская Федерация ведёт активную работу по обновлению ледокольного флота и портовой инфраструктуры. В Российской Федерации СМП рассматривается как исторически сложившаяся национальная транспортная коммуникация, что, на наш взгляд, соответствует нормам международного права. Вместе с тем, не все зарубежные государства придерживаются российского подхода к правовому статусу СМП. Так, например, Соединенные Штаты Америки заявляют о необходимости интернационализации СМП по мере освобождения данной водной артерии от льда. В качестве примера усиливающегося политического и экономического давления западных стран в отношении России можно привести отказ нескольких крупных компаний от использования СМП для перевозки грузов под предлогом охраны окружающей среды. Ряд других зарубежных стран также имеют свою точку зрения по вопросу определения правового статуса и режима судоход-

\footnotetext{
${ }^{1}$ Лариса Владиславовна Вереина, кандидат юридических наук, доцент кафедры международного права Московского государственного института международных отношений (Университета) МИД России, г. Москва, Россия.

${ }^{2}$ Анна Викторовна Котлова, кандидат юридических наук, преподаватель кафедры публичного права Одинцовского филиала Московского государственного института международных отношений (Университета) МИД России, г. Москва, Россия.

Для циитирования: Вереина Л. В., Котлова А. В. Правовой статус Северного морского пути: французская доктрина // Азиатско-Тихоокеанский регион: экономика, политика, право. 2019. № 3. С. 70-76.

(C) Вереина Л. В., Котлова А. В., 2019
} 
ства по Северному морскому пути. Поскольку Франция является одним из ведущих государств Европейского союза, членом Североатлантического альянса, одним из двенадцати неарктических государств, являющихся наблюдателями в Арктическом совете, а также государством, которое обозначило себя как «полярное государство», считаем целесообразным рассмотреть французскую международноправовую доктрину о статусе Северного морского пути.

Ключевые слова: Арктика, Северный морской путь, Франция, доктрина, международное право, Российская Федерация, морское право, Арктический совет, экология, охрана окружающей среды.

Vereina Larisa V. ${ }^{1}$, Ph.D (Law), Moscow State University of International

Relations (MGIMO), Chair of International Law, Associate Professor

E-mail: vereinalarisa@mail.ru

Kotlova Anna V. ${ }^{2}$, Ph.D (Law), Moscow State University of International Relations (MGIMO) (Odintsovo branch), Chair of Public Law, lecturer

E-mail: a.kotlova@odin.mgimo.ru

\section{THE LEGAL STATUS OF THE NORTHERN SEA ROUTE: FRENCH DOCTRINE}

Abstract. The Government of the Russian Federation approved the plan for the development of the Northern Sea Route (hereinafter - SMP) until 2035. The cargo turnover of the Northern Sea Route by 2035 is expected to increase eight-fold up to 160 million tons. The Russian Federation is actively working to renew the icebreaker fleet and port infrastructure. In Russia, the SMP is regarded as a historically established national transport communication which, in our opinion, corresponds to the norms of international law. At the same time, not all foreign states adhere to the Russian approach to the legal status of the SMP. For example, the USA advocates the internationalization of the SMP. The popular wisdom is that the SMP is the international strait. As an example of the increasing political and economic pressure of Western countries toward Russia is the refusal of several large companies to use SMP under the pretext of environmental protection. As France is one of the leading states of the European Union, a member of the

\footnotetext{
${ }^{1}$ Larisa V. Vereina, Ph.D. (Law), Associate Professor, Department of International Law, Moscow State Institute of International Relations (University), Ministry of Foreign Affairs of Russia, Moscow, Russia.

${ }^{2}$ Anna V. Kotlova, Ph.D. (Law), lecturer in the Department of Public Law, Moscow State Institute of International Relations (University), Odintsovo Branch, Ministry of Foreign Affairs of Russia, Moscow, Russia.

For citing: Vereina L. V. Kotlova A. V. The legal status of the Northern Sea Route: French doctrine // PACIFIC RIM: Economics, Politics, Law. 2019. № 3. P. 70-76.
} 
NATO, one of the twelve non-Arctic states that are observers in the Arctic Council and a state which identifies itself as a "polar" state, examining the French international legal doctrine concerning the status of the Northern Sea Route has to be relevant.

Keywords: the Arctic, the Northern Sea Route, France, doctrine, International Law, the Russian Federation, law of the sea, the Arctic Council, environmental protection.

В августе 2019 г. стало известно, что крупнейшая во Франции компания, предоставляющая услуги контейнерных перевозок, CMA CGM Group, отказалась пользоваться для доставки своих грузов в Азию Северным морским путём. Компания объяснила свое решение соображениями экологической безопасности. Вместе с тем, было бы наивно полагать, что французские компании не заинтересованы в сокращении издержек на транспортировку товаров, используя СМП. Следовательно, можно сделать вывод, что не существует единого подхода, согласованного мнения относительно правового статуса СМП и режима судоходства по данному маршруту. Определим базовые отличия российской и западной (в частности французской) международно-правовой позиции относительно статуса Северного морского пути.

Во-первых, Российская Федерация рассматривает Северный морской путь как «исторически сложившуюся национальную транспортную коммуникацию» [5], что закреплено в Федеральном законе от 28 июля 2012 г. № 132 - ФЗ «О внесении изменений в отдельные законодательные акты Российской Федерации в части государственного регулирования торгового мореплавания в акватории Северного морского пути». Следовательно, плавание по СМП осуществляется в соответствии с общепризнанными принципами и нормами международного права, международными договорами Российской Федерации, а также другими федеральными законами и издаваемыми в соответствии с ними иными нормативными правовыми актами» [5]. Навигация по СМП иностранных судов возможна лишь с разрешения России и под её контролем. Вполне логично, на наш взгляд, что Российская Федерация рассматривает СМП как единую транспортную артерию, а, следовательно, правовой режим СМП не должен меняться в зависимости от того, через какие виды морских пространств пролегает тот или иной участок данного морского пути. Здесь появляется первое противоречие с западной правовой доктриной, а именно, французские специалисты настаивают, что на участках СМП, проходящих через исключительную экономическую зону России, должны действовать нормы Конвенции по морскому праву 1982 г., в соответствии с которыми «в исключительной экономической зоне все государства, как прибрежные так и не имеющие выхода к морю, пользуются свободами судоходства и другими правомерными с точки зрения международного права видами использования моря, относящимся к таким свободам». 
Таким образом, во французской доктрине предлагается «разделить» правовой режим СМП в зависимости от видов морских пространств, по которым пролегает данный водный маршрут. Из данного утверждения следует, согласно западной доктрине, что и разрешительный порядок прохода по СМП не имеет под собой достаточного правового обоснования.

С таким мнением западных правоведов нельзя согласиться. По мнению А. Н. Вылегжанина, «главное географическое, климатическое и политико-правовое своеобразие морских районов Северного Ледовитого океана состоит в том, что даже в условиях таяния льдов безопасно осуществлять судоходство, рыболовство, иную экономическую деятельность в этих экстремально суровых полярных районах неарктическое государство может только при согласии соответствующего арктического прибрежного государства, при опоре на его береговую инфраструктуру, его технические возможности связи, реагирования на чрезвычайные ситуации, поиска и спасания людей и грузов, устранения последствий загрязнения морской среды и т.д.» [4]. Кроме того, нахождение плавучего транспортного средства на участках СМП, выходящих за пределы территории Российской Федерации, невозможно без предварительного либо последующего пересечения российских акваторий Северного Ледовитого океана, а также без ледокольно-лоцманской проводки и ледовой авиаразведки [1].

Во-вторых, важнейшей нормой, относящейся к регулированию Северного морского пути, является ст. 234 Конвенции по морскому праву 1982 г. Данная статья устанавливает, что «прибрежные государства имеют право принимать и обеспечивать соблюдение недискриминационных законов и правил по предотвращению, сокращению и сохранению под контролем загрязнения морской среды с судов в покрытых льдами районах в пределах исключительной экономической зоны, где особо суровые климатические условия и наличие льдов, покрывающих такие районы в течение большей части года, создают препятствие либо повышенную опасность для судоходства, а загрязнение морской среды могло бы нанести тяжелый вред экологическому равновесию или необратимо нарушить его» [3]. Несмотря на утверждения некоторых западных юристов о том, что Россия расширительно толкует положения данной нормы, стоит отметить, что именно в целях предотвращения загрязнения морской среды Российская Федерация установила разрешительный порядок прохода по СМП.

Французская доктрина строится на убеждении, что не существует международного политического соглашения относительно понятия «покрытый льдом район», так как даже формально свободные от льда воды могут содержать небольшое количество ледяного покрова [6]. Отмечается также, что статья 234 Конвенции ООН по морскому праву 1982 г. имеет двусмысленный, неоднозначный характер, в частности, формулировка «в таких законах и правилах должным образом принимаются во внимание судоходство и защита и сохранение морской среды на основе 
имеющихся наиболее достоверных научных данных» [3]. Вероятно, целью такой формулировки было установить баланс между правом прибрежного государства принимать меры по охране окружающей среды и правами других государств на свободу прохода. Французские исследователи убеждены, что Россия использует ссылку на статью 234 Конвенции ООН 1982 г. с целью ущемить права других стран на свободу судоходства [6]. По их мнению, Российская Федерация ввела систему обширного контроля, включая обязательное получение разрешений для судов и плату за транзит и в случае необходимости может использовать данные меры как механизм политического влияния [6].

Наконец, третье базовое отличие правовой позиции России и Франции (как и некоторых других западных государств) состоит в том, что, в соответствии с западным подходом, к российским арктическим проливам должно быть применено право транзитного прохода [2]. Такая точка зрения Российской Федерацией не принимается по вполне аргументированным доводам. Так, указанные проливы никогда не использовались для международного судоходства, что является важнейшим требованием для отнесения пролива к данной категории. Напомним, что для отнесения пролива к категории международного необходимо одновременное соблюдение двух условий, а именно: определённое географическое положение проливов и их использование для международного судоходства [2].

Стоит обратить внимание на иерархию источников правового регулирования СМП в понимании представителей французской международно-правовой доктрины. Так, основным применимым источником, по мнению французских специалистов, является Конвенция по морскому праву 1982 г., далее следуют решения Арктического совета, затем документы Международной морской организации, и только потом национальное законодательство Российской Федерации. Чем обоснован такой подход и по какой причине решения Арктического совета имеют приоритет над национальным законодательством Российской Федерации - не поясняется.

Учитывая изложенные различия в правовых подходах к определению режима судоходства по Северному морскому пути, можно сделать следующие выводы. Во-первых, основу правового статуса Северного Ледовитого океана составляют, помимо Конвенции 1982 г., национальное законодательство, а также двусторонние соглашения прибрежных арктических государств. Кроме этого, следует напомнить, что СМП имеет статус исторических вод Российской Федерации, а это, в свою очередь, означает, что государство осуществляет свой суверенитет над данной акваторией, которая имеет важнейшее экономическое и стратегическое значение для страны, на протяжении длительного времени, без фактических возражений со стороны других государств [2]. Считаем, что соответствующие правовые доводы должны и в будущем составлять основу позиции Российской Федерации относительно правового режима судоходства по Северному морскому пути. 


\section{Список литературы}

1. Гаврилов, В. В. Правовой статус Северного морского пути Российской Федерации // Журнал российского права. - 2015. - № 2 (218). - С. 147-157.

2. Гудев, П. Северный морской путь: национальная или международная транспортная артерия? // РСМД. - 2018. - URL: https://russiancouncil.ru/analyticsand-comments/analytics/severnyy-morskoy-put-natsionalnaya-ili-mezhdunarodnayatransportnaya-arteriya/ (дата обращения: 31.12.2019).

3. Конвенция по морскому праву от 10 декабря 1982 г. - URL: https://www.un.org/Depts/los/convention_agreements/texts/unclos/unclos_r.pdf (дата обращения: 31.12.2019).

4. Международное сотрудничество в области охраны окружающей среды, сохранения и рационального управления биологическими ресурсами в Северном Ледовитом океане : материалы Международного научного симпозиума (Москва, 4 сент. 2012 г., РСМД) : рабочая тетрадь / [А. Н. Вылегжанин (рук.) [и др.]] ; [гл. ред. И. С. Иванов] ; Российский совет по междунар. делам (РСМД). - Москва : Спецкнига, 2012. - 88 с.

5. О внесении изменений в отдельные законодательные акты Российской Федерации в части государственного регулирования торгового мореплавания в акватории Северного морского пути : Федеральный закон от 28 июля 2012 г. № 132Ф3. - URL: http://www.consultant.ru/document/cons_doc_LAW_133277/ (дата обращения: 31.12.2019).

6. Commercial Arctic shipping through the Northeast Passage: routes, resources, governance, technology and infrastructure / A. Farré A., D. O'Leary, E. Petersen [et al.]. - DOI 10.1080/1088937X.2014.965769 // Polar Geography. - 2014. - Vol. 37, iss. 4. - P. 298-324. - URL: https://www.tandfonline.com/doi/pdf/10.1080/1088937X.2014. 965769? needAccess=true\& (дата обращения: 31.12.2019).

\section{References}

1. Gavrilov V.V. Pravovoi status Severnogo morskogo puti Rossiiskoi Federatsii [The legal status of the Northern Sea Route of the Russian Federation]. Zhurnal rossiiskogo prava, 2015, no. 2, iss. 218, pp. 147-157.

2. Gudev P. Severnyi morskoi put': natsional'naya ili mezhdunarodnaya transportnaya arteriya? [The Northern Sea Route: national or international waterway?]. RSMD. 2018. Available at: https://russiancouncil.ru/analytics-and-comments/analytics/s evernyy-morskoy-put-natsionalnaya-ili-mezhdunarodnaya-transportnaya-arteriya/ (accessed 31 December 2019). 
3. United Nation Convention on the Law of the Sea. 1982. Available at: https://www.un.org/Depts/los/convention_agreements/texts/unclos/unclos_r.pdf (accessed 31 December 2019). (In Russian).

4. Ivanov I. S., ed. Mezhdunarodnoe sotrudnichestvo v oblasti okhrany okruzhayushchei sredy, sokhraneniya i ratsional'nogo upravleniya biologicheskimi resursami $v$ Severnom Ledovitom okeane: Materialy Mezhdunarodnogo. nauchnogo simpoziuma (Moskva, 4 sent. 2012 g., RSMD): rabochaya tetrad' [International cooperation in the sphere of environmental protection and sustainable management of biological resources: Proceedings of the International Scientific Symposium (Moscow, September 4, 2012, INF): workbook]. Moscow: Spetskniga Publ., 2012. 88 p.

5. On amendments to certain legislative acts of the Russian Federation regarding state regulation of merchant shipping in the waters of the Northern Sea Route: Federal Law of July 28, 2012 No. 132-FZ. Available at: http://www.consultant.ru/docum ent/cons_doc_LAW_133277/(accessed 31 December 2019). (In Russian).

6. Farré A., O'Leary D., Petersen E. et al. Commercial Arctic shipping through the Northeast Passage: routes, resources, governance, technology and infrastructure. Polar Geography, 2014, vol. 37, iss. 4, pp. 298-324. DOI 10.1080/1088937X.2014.965769. Available at: https://www.tandfonline.com/doi/pdf/10.1080/1088937X.2014.96576 9? needAccess $=$ true \& (accessed 31 December 2019). 